\title{
Peningkatan Minat Baca pada Peserta Didik Sekolah Dasar Negeri 202/IX Bukit Makmur Kabupaten Muaro Jambi
}

\author{
Siti Nurkayati \\ SDN 202/IX Bukit Makmur Kab. Muaro Jambi \\ Correspondence email: sitinurkayati.202@yahoo.com
}

\begin{abstract}
Abstrak. Membaca adalah aktivitas yang kompleks dengan melibatkan sejumlah kegiatan dengan tindakan yang terpisah-pisah. Untuk mencapai keberhasilan membaca yang baik salah satunya yaitu adanya minat, minat yang kuat akan berdampak pada terlaksana segala kegiatan secara efektif dan efesien. Minat baca peserta didik SDN 202/IX Bukit Makmur jika diamati secara keseluruhan seimbang atau hampir sama. Namun tenyata terdapat perbedaan minat membaca antara peserta didik laki-laki dan perempuan. Hasil Identifikasi Masalah maka muncul beberapa masalah di SDN 202/IX Bukit Makmur yang di identifikasikan sebagai berikut: (a) Peserta didik belum terlihat memanfaatkan sumber belajar dan sarana belajar seperti buku dan pelajaran dengan optimal, (b) peserta didik belum aktif membaca buku di perpustakaan. Berdasarkan permasalahan yang telah dirumuskan, maka yang menjadi fokus penilitian ini adalah: Upaya yang di lakukan guru kelas untuk lebih meningkatkan minat baca peserta didik kelas III di SDN 202/IX Bukit Makmur Kecamatan Sei Bahar Sei Bahar Kabupaten Muaro Jambi. Penelitian ini bertujuan untuk mendeskripsikan upaya guru meningkatkan minat baca pada peserta didik kelas III SDN 202/IX Bukit Makmur. Penelitian ini merupakan penelitian kualitatif jenis deskriptif. Subjek penelitian ini adalah 1 guru kelas dan 29 peserta didik III SDN 202/IX Bukit Makmur. Teknik pengumpulan data menggunakan observasi dan wawancara. Penelitian ini menggunakan teknik analisis data melalui reduksi data, penyajian data, dan penarikan kesimpulan. Hasil penelitian menunjukkan bahwa upaya guru meningkatkan minat baca pada peserta didik kelas III SDN 202/IX Bukit Makmur, dapat ditingkatkan melalui kegiatan: (1) Mendorong peserta didik bercerita tentang apa yang telah didengar atau dibacanya, (2) Membeli buku yang menarik minat baca, (3) Menukar buku dengan teman, (4) Memberikan buku sebagai hadiah, dan (5) Menyediakan waktu membaca.
\end{abstract}

Kata kunci: Bahasa; Guru; Minat baca; Peserta didik

\begin{abstract}
Reading is a complex activity that directs large numbers of separate actions. One of the ways to achieve good reading success is interest. because without interest all activities will be carried out less effectively and efficiently. The reading interest of SDN 202 / IX Bukit Makmur students if observed as a whole is balanced or almost the same. However, it turns out that there are differences in reading interest between male and female students. The results of problem identification then emerged several problems at SDN 202 / IX Bukit Makmur which were identified as follows: (a) Students have not been seen to optimally utilize learning resources and learning facilities such as books and lessons, (b) students have not actively read books in the library. Based on the above problems, this research focuses on: Efforts made by classroom teachers to further increase the reading interest of class III students at SDN 202 / IX Bukit Makmur, Sei Bahar Sei Bahar District, Muaro Jambi Regency. This study aims to describe the teacher's efforts to increase reading interest in grade III SDN 202 / IX Bukit Makmur. This research is a descriptive qualitative research. The subjects of this study were 1 class teacher and 29 students III SDN 202 / IX Bukit Makmur. Data collection techniques using observation and interviews. Data analysis techniques in this study used data reduction, data presentation, and drawing conclusions. The results showed that the teacher's efforts to increase reading interest in third grade students of SDN 202 / IX Bukit Makmur, namely: (1) Encouraging children to tell stories about what they have heard or read, (2) Buying books that attract reading interest, (3) Swapping books with friends, (4) giving books as gifts, and (5) providing reading time. The reading interest of the third grade students was shown by the presence of several students visiting the library to borrow books or read books during recess.
\end{abstract}

Keywords: language; teacher; reading interest; student

\section{PENDAHULUAN}

Dalam dunia pendidikan salah satu yang wajib dilakukan oleh peserta didik yaitu membaca. Kegiatan membaca akan sangat diperlukan dalam kehidupan bermasyarakat, dikarenkan dalam aktifitas bermasyarakat akan terjadi proses komunikasi. Membaca merupakan jendela untuk mengakses ilmu pengatuhan baik di dunia pendidikan maupun di masyarakat. Menurut Crawley dan Mountain dalam (Farida Rahim, 2008) membaca adalah suatu yang rumit yang melibatkan banyak hal, tidak sekedar melafalkan tulisan, tapi juga melibatkan aktivitas visual, berpikir, psikolinguistik, dan metakognitif. Menurut Sudarso, (2005). Membaca merupakan suatu kegiatan yang kompleks dengan melibatkan sebagian besar dengan tindakan yang terpisah. Kegiatan ini meliputi: orang yang harus menggunakan pengertian dan khayalan, mengamati dan mengingat-ingat. Seseorang dapat membaca harus didukung dengan aktifitas menggerakan mata atau dengan menggunakan pikiran. Kecepatan dan pemahaman membaca sangat tergantung pada kemampuan dalam menjalankan organ tubuh yang diperlukan untuk aktifitas membaca.

Guru dalam bahasa sanskerta diartikan sebagai 
seorang pangajar suatu ilmu. Makna kata guru dalam bahasa Indonesia, adalah pendidik profesional dengan tugas utama mendidik, mengajar, membimbing, mengarahkan, melatih, menilai, dan mengevaluasi peserta didik. Guru merupakan tenaga profesional yang harus memiliki kompetensi dan kualifikasi berdasarkan standar tertentu dalam suatu proses sertifikasi. Terkait kompetensi yang harus dimiliki guru Mulyasa (2017) mengemukakan pendapat bahwa guru harus memiliki standar kompetensi tertentu, meliputi tanggung jawab, disiplin wibawa, dan kemandirian. Guru diharapkan memiliki kemampuan dalam mengambil keputusan secara mandiri, khususnya terkait dengan proses pembelajaran dan pembentukan kompetensi peserta didik, serta bertindak sesuai dengan kondisi peserta didik, dan lingkungan sekitarnya. Guru seharusnya memiliki kompetensi dalam bertindak dan mengambil keputusan secara cepat tepat waktu, tepat sasaran terutama berkaitan dengan masalah pembelajaran dan paserta didik.

Menurut Mulyasa, (2017), seorang guru harus memiliki kemampuan menghubungkan suatu yang sedang dipelajari peserta didik dengan suatu yang telah diketahuinya, dan pada waktu yang sama memberikan tambahan pengalaman kepada peserta didik. Selanjutnya Guru harus mampu membuat pelajaran menjadi lebih bermakna, dan hidup melalui antusias dan semangat peserta didik untuk dapat berpartisipasi dalam proses pembelajaran. Terkait kompetensi teknis guru dalam proses pembelajaran dan pembentukan kompetensi peserta didik, guru melakukan banyak hal terkait adanya keinginan untuk meningkatkan kemampuan dalam melaksakannya, sehingga hasilnya pun semakin baik yang diwujudkan dalam prestasi belajar peserta didik.

Selain berkaitan dengan kompetensi guru dan peserta didik, kegiatan membaca bagi peserta didik dipengaruhi pula oleh faktor minat. Terkait konsep minat ada beberapa ahli yang memberikan formulasi diantaranya Nuryanti (2008) mengemukakan minat adalah kecenderungan seseorang terhadap sesuatu atau bisa dikatakan apa yang disukai seseorang untuk dilakukan. Selanjutnya Slameto (2003) mengemukakan pada dasarnya setiap orang akan lebih senang melakukan sesuatu yang sesuai dengan minatnya (yang disukai) dari pada melakukan sesuatu yang kurang disukai. Minat merupakan suatu keterkaitan suatu hubungan antara diri sendiri denga situasi diluar diri.

Minat membaca peserta didik di sekolah dasar dipengaruhi pula oleh faktor eksternal dan internal peserta didik itu sendiri. Demikian pula dengan peserta didik kelas III SDN 202/IX Bukit Makmur, yang merupakan peserta didik sekolah dasar kelas rendah. Berdasarkan observasi yang peneliti lakukan terhadap peserta didik kelas III terkait tentang kemampuan dan minat membaca peserta didik, diketahui peserta didik memiliki keberagaman kemampuan membaca cerita mini, ada peserta didik yang gemar membaca buku pelajaran, ada peserta didik yang gemar membaca buku kelas IV yang berada diperpustakaan dan ada pula peserta didik suka membaca komik bergambar dan berwarna. Akan tetapi pada saat pelaksanaan proses pembelajaran, peserta didik belum dapat memanfaatkan sarana pembelajaran dan bahan belajar seperti buku pelajaran dan buku latihan kerja peserta didik secara obtimal. Peserta didik belum mempunyai inisiatif sendiri untuk mempelajari materi dari sumber lain selain dari penjelasan guru. Pada waktu guru meminta peserta didik membuka dan membaca buku pelajaran, maka peserta didik baru melakspeserta didikannya..

Minat baca peserta didik kelas III SDN 202/IX Bukit Makmur diketahui pada observasi awal secara keseluruhan seimbang atau hampir sama. Tetapi hasil analisa data awal observasi secara lebih detail ditemukan perbedaan minat membaca antara peserta didik laki-laki dan perempuan. Peserta didik laki-laki kebanyakan suka bermain dibanding membaca buku. Sementara siswi perempuan lebih suka membaca. Data observasi awal tentang perbedaan minat membaca peserta didik laki-laki dan perempuan di kelas III adalah sebagai berikut : jumlah peserta didik perempuan sebanyak 10 peserta didik maka sementara peserta didik laki-laki yang memiliki minat membaca sebanyak $3-4$ peserta didik saja.

Perbedaan minat baca peserta didik laki-laki dan perempuan pada kelas III sebagaimana data awal yang telah disebutkan sebelumnya, mengundang keingin tahuan peneliti untuk mengkaji lebih detail terkait strategi guru meningkatkan minat baca peserta didik kelas III SDN 202/IX Bukit Makmur, dengan pertimbangan bahwa buku adalah media belajar yang sangat efektif, dalam merangsang pertumbuhan dan perkembangan otak peserta didik, untuk itu diperlukan buku-buku bermutu yang dapat menyehatkan mental dan psikologi bagi para peserta didik.

Konsep minat juga dikemukakan Ormrod (2008) "minat ( interest) persepsi bahwa suatu aktivitas menimbulkan rasa ingin tahu dan menarik; biasanya disertai oleh keterlibatan kognitif dan efek yang positif. Konsep minat juga dikemukakan oleh Getzel dalam (Mimin Haryati, 2008) yang menjelaskan bahwa secara umum termasuk karateristik efektif dan jika seseorang memiliki minat terhadap sesuat maka orang tersebut akan melakukan langkah-langkah nyata untuk mencapainya.

Faktor minat mempunyai pengaruh yang besar karena dalam kegiatan membaca, bila sesuatu yang dilakukan tidak sesuai dengan minat peserta didik maka peserta didik tersebut tidak akan melakukan suatu hal yang sebaik-baiknya, sebab tidak ada daya tarik baginya. Sedangkan bila suatu itu menarik minat peserta didik, maka ia akan mudah dipelajari dan disimpan karena ada minatnya. Fungsi minat lebih besar sebagai motivating 
force yaitu sebagai kekuatan yang mendorong peserta didik untuk melakukan sesuatu.

Tingginya minat peserta didik pada suatu pelajaran tertentu akan memotivasinya untuk tekun belajar, hal ini berbeda dengan peserta didik yang memiliki sikap hanya menerima pelajaran. Peserta didik hanya mau mengikuti pelajaran tapi sulit untuk terus tekun karena tidak ada faktor yang memotivasi. Dari beberapa pendapat di atas dapat disimpulkan bahwa untuk memperoleh hasil yang baik seorang peserta didik harus mempunyai minat dalam membaca sehingga akan mendorong peserta didik untuk terus berusaha menerapkannya.

Terkait dengan aktivitas membaca, beberapa ahli mengemukakan konsep membaca. Marksheffel mendefinisikan membaca itu sebagai suatu kegiatan kompleks dan disengaja, terkait dengan hal ini membaca merupakan suatu proses berpikir yang di dalamnya terdiri dari pelbagai aksi berpikir yang bekerja secara untuk mencapai satu tujuan yaitu memahami makna paparan tertulis secara keseluruhan. Selanjutnya konsep membaca dikemukakan pula oleh Bafadal (2009) bahwa rangkaian aktivitas membaca tersebut berupa memperoleh pengetahuan dari simbol huruf atau gambaran yang diamati, pemecahan masalah yang timbul serta mengartikan simbol-simbol huruf atau gambar-gambar dan sebagainya.

Tujuan utama membaca adalah memperoleh pemahaman. Pemahaman dalam membaca merupakan teknik membaca yang berusaha memahami isi bacaan /teks secara menyeluruh. Memahami bacaan secara baik apabila seseorang memiliki kemampuan sebagai berikut: (a) Kemampuan memahami arti kata dan ungkapan yang digunakan penulis, (b) Kemampuan memahami makna tersurat dan makna tersirat, dan (c) Kemampuan membuat kesimpulan. Faktor kemampuan membaca tersebut di atas akan diperoleh seseorang yang telah mempunyai tingkat kemampuan membaca tinggi. Tingkat pemahaman membaca seseorang tetap terbatas, dikarenakan tidak semua orang dapat memahami maksud atau makna yang persis sama dengan yang dimaksud oleh penulis (Samsul Somadayo, 2001). Berdasarkan pendapat beberapa ahli di atas, tujuan membaca dapat disimpulkan sebagai usaha untuk mendapatkan informasi, memberikan penilaian yang kritis terhadap suatu bacaan dan dapat memperoleh kesenangan.

Berdasarkan hasil observasi awal tentang minat baca peneliti melakukan identifikasi masalah yang menjadi faktor penyebab rendahnya minat baca peserta didik kelas III di SDN 202/IX Bukit Makmur sebagai berikut: (a) Peserta didik belum memanfaatkan buku pelajaran dengan optimal, (b) Peserta didik lebih suka bermain dari pada membaca buku, (c) Peserta didik belum aktif membaca buku di perpustaan sekolah, meskipun sudah ada jadwal kujungan khusus keperputakaan, (d) Peserta didik belum memiliki inisiatif sendiri untuk membaca buku pelajaran atau buku penunjang lain sebagai upaya menambah wawasan dan pengetahuan.

Berdasarkan permasalahan di atas, maka penilitian ini fokus pada: Upaya yang di lakukan guru kelas untuk meningkatkan minat baca peserta didik kelas III di SDN 202/IX Bukit Makmur Kecamatan Sei Bahar Kabupaten Muaro Jambi. Berdasarkan fokus penelitian, maka rumusan masalah pada penelitian ini adalah: Bagaimana upaya yang dilakukan guru kelas untuk meningkatkan minat baca peserta didik kelas III SDN 202/IX Bukit Makmur?

Penelitian ini bertujuan untuk mengetahui upaya yang dilakukan guru kelas dalam meningkatkan minat baca peserta didik kelas III SDN 202/IX Bukit Makmur, sedangkan manfaat yang diharapkan pada penelitian ini dapat memberikan manfaat praktis bagi peserta didik berupa masukan tentang faktor yang menjadi pendorong dan penghambat minat baca dalam diri peserta didik. Manfaat bagi guru dapat memberikan gambaran dan informasi mengenai kegiatan yang dapat menumbuhkan minat baca peserta didik serta hasil penelitian ini diharapkan dapat dijadikan bahan masukan bagi kepala sekolah dalam meningkatkan minat baca peserta didik kelas III SDN 202/IX Bukit Makmur.

\section{METODE}

Pada penelitian ini menggunakan pendekatan kualitatif. Penelitian kualitatif adalah bersumber pada pengamatan kualitatif yang bertentangan pengamatan kuantitatif. Pengamatan kualitatif menggunakan konsep pengukuran tingkat suatu ciri tertentu. Peneliti melakukan suatu pengamatan untuk mengetahui apa yang menjadi ciri sesuatu itu.

Penelitian kualitatif sebagaimana dikemukakan oleh Moleong (2007) adalah upaya untuk menyajikan sejumlah fakta sosial, berdasarkan perspektifnya dari segi konsep, perilaku, persepsi dan persoalan tentang manusia yang diteliti. Berdasarkan defenisi di atas terlihat peran penting dari apa yang harus diteliti yaitu konsep, perilaku, persepsi, dan persoalan tentang manusia yang diteliti. Penelitian ini, memilih penelitian kualitatif yang bersifat deskriptif. Metode deskriptif kualitatif digunakan untuk meneliti status kelompok manusia, suatu objek, suatu set kondisi, suatu sistem pemikiran, atau suatu kelas perstiwa pada masa dikemukan oleh Nazir dalam (Andi Prastowo, 2012).

Penelitian dilaksanakan di kelas III SDN 202/IX Bukit Makmur Kecamatan Sei Bahar Kabupaten Muaro Jambi. Waktu penelitian dilakspeserta didikan dengan alokasi waktu sejak bulan September sampai dengan bulan Nopember 2019. Subjek utama penelitian ini adalah peserta didik kelas III SDN 202/IX Bukit Makmur terdiri dari 29 peserta didik. Objek penelitian adalah data dan informasi yang diperoleh dari subjek 
penelitian. Objek dalam penelitian ini adalah Upaya Guru Meningkatkan Minat Baca Pada Peserta didik Kelas III SDN 202/IX Bukit Makmur.

Sumber Data penelitian ini, bersumber dari data primer yang diperoleh dari hasil wawancara dan pengamatan terhadap pihak terkait yaitu peserta didik, guru, dan staf sekolah terutama perpustakaan yang berkaitan dengan minat baca peserta didik.

Pengumpulan data penelitian merupakan langkah yang paling utama dalam penelitian, dikarenakan tujuan utama dalam penelitian adalah mendapatkan data. Pengumpulan data pada penelitian kualitatif dapat dilakukan pada kondisi alamiah (natural setting), sumber data sekunder, dan sumber data primer. Teknik pengumpulan data lebih banyak dilakukam dengan melakspeserta didikan kegiatan observasi atau pengamatan, wawancara yang mendalam, dan dokumentasi.

Analisa data penelitian merupakan proses mengidentifikasi, memeriksa dan menyusun secara sistematis data dan informasi yang diperoleh dari hasil wawancara, catatan lapangan, dan dokumentasi, dengan cara mengorganisasikan data ke dalam kategori, menjabarkan ke dalam unit-unit, melakukan sintesa, menyusun pola, memilih skala priotitas yang akan dipelajari, dan menarik kesimpulan agar mudah dipahami. Proses analisis data kualitatif adalah suatu analisis yang terdiri dari tiga alur kegiatan yang terjadi secara bersamaan, yaitu reduksi data, penyajian data, dan penarikan kesimpulan atau verifikasi.

\section{HASIL DAN PEMBAHASAN}

Upaya yang dapat dilalukan guru kelas untuk lebih meningkatkan minat baca pada peserta didik saat pembelajaran

\section{Bercerita Tentang Hasil Bacaan Di Depan Kelas}

Berdasarkan hasil pengamatan, pada saat proses pembelajaran peserta didik maju kedepan kelas untuk bercerita tentang bacaannya. Senada dengan hasil wawancara peserta didik didapatkan bahwa peserta didik kelas III maju kedepan untuk menceritakan kembali apa isi cerita tersebut, dari hasil wawancara dengan peserta didik, dapat disimpulkan Rata-rata peserta didik dapat bercerita setelah membaca buku.

Pernyataan ini diperkuat oleh hasil wawancara yang dilakukan dengan guru kelas III, didapatkan bahwa rata-rata peserta didik dapat maju kedepan mencerikan isi ulang bacaaan tersebut. Guru Kelas mengemukakan bahwa dia memberi latihan kepada peserta didik untuk bercerita dengan memberi tugas peserta didik untuk ke pasar atau supermarket, lalu kemudian disuruh maju ke depan kelas untuk bercerita. Berdasarkan wawancara menunjukkan bahwa bercerita di depan kelas tentang apa yang telah dibaca peserta didik telah dilakspeserta didikan dengan baik hal ini sesuai dengan hasil obsevasi bahwa peserta didik diminta maju kedepan untuk mencaritakan kembali isi bacaan yang telah dibacanya.

\section{Bertukar Buku Dengan Teman}

Berdasarkan hasil pengamatan, pada saat proses pembelajaran peserta didik menukar buku sebangkunya baik dikelas maupun di perpustakan. Senada dengan hasil wawancara peserta didik didapatkan bahwa peserta didik kelas III, menukarkan bukunya dengan teman sebangkunya lalu membacanya begitu jaga pada saat berkunjung di perpustakaan, dari hasil wawancara dapat disimpulkan. Peserta didik sering membaca buku cerita maupun buku pelajaran dengan teman-temannya untuk dibaca. Berdasarkan hasil wawancara dapat disimpulkan bahwa peserta didik lebih suka bertukar buku dengan teman-temannya karena bagus untuk dibaca.

Kesimpulan diatas diperkuat oleh hasil wawancara yang dilakukan dengan guru kelas III. Guru kelas menyatakan bahwa di sekolah ada kegiatan literasi pagi selama 15 menit sebelum memulai mata pelajaran, peserta didik-peserta didik sudah mulai membaca. Program sekolah yang sudah melaksanan kegiatan literasi ini bertujuan mendorong agar peserta didikpeserta didik gemar membaca. Selain kegiatan literasi pagi, peserta didik diberikan tugas mata pelajaran yang harus diselesaikan. Dalam penyelesaian tugas ini peserta didik diwajibkan ke perpustakaan untuk membaca, tapi sebagian peserta didik semangat membaca sementara sebagian tidak semangat membaca. Berdasar wawancara dapat disimpulkan Guru mengatakan bahwa di sekolah ada program literasi yang merupakan salah satu upaya untuk membiasakan membaca sebelum pelajaran di mulai.

Hasil penelitian menunjukkan bahwa minat baca peserta didik melalui kegiatan tukar buku dengan teman sudah dilakukan, hal ini sesuai hasil observasi bahwa peserta didik senang menukar buku dengan teman sebangkunya kemudian membacanya dalam waktu 15 menit sesuai denganprogram literasi sekolah membaca 15 menit sebelum memulai mata pelajaran peserta didik sudah mulai membaca.

Minat adalah keinginan seseorang terhadap sesuatu atau bisa dikatakan apa yang disukai seseorang untuk dilakukan. Nuryanti (2008) mengemukakan bahwa "setiap orang akan lebih suka melakukan sesuatu yang sesuai dengan minatnya (kegemarannya) dari pada melakukan sesuatu yang kurang disukai”. Minat terhadap suatu merupakan hasil belajar dan mendukung hasil belar selanjutnya. Minat seseorang terhadap sesuatu tidak merupakan hal yang krusial untuk dapat mempelajari sesuatu tersebut, asumsi umum menyatakan bahwa minat akan membantu seseorang yang mempelajarinya. (Slameto, 2003). Sedangkan menurut Jeanne Ellis Ormrod (2008) "minat (interest) persepsi bahwa suatu aktivitas menimbulkan rasa ingin tahu dan menarik; biasanya disertai oleh keterlibatan kognitif dan efek yang positif. 
Minat merupakan keinginan untuk memehami kata demi kata dan isi yang terkandung dalam teks bacaan tersebut, sehimgga pembaca dapat memahami hal-hal yang dituangkat dalam bacaan itu. Hal ini sependapat dengan Tampubolon dalam (Dalman, 2014) bahwa minat baca adalah kemauan atau keinginan seseorang untuk mengenali huruf untuk menangkap makna dari tulisan tersebut.

Upaya yang dapat dilalukan guru kelas untuk lebih meningkatkan minat baca pada peserta didik saat diluar jam pelajaran

\section{Beli buku yang menarik minat baca peserta didik}

Berdasarkan hasil pengamatan, pada saat proses pembelajaran peserta didik maju kedepan kelas. Senada dengan hasil wawancara peserta didik didapatkan bahwa peserta didik kelas III, membeli buku cerita seperti majalah bobo, princes dan komik, dari hasil wawancara dengan peserta didik, dapat disimpulkan bahwa peserta didik dapat tertarik membaca buku dengan membeli buku sesuai dengan keinginan mereka. Hal ini diperkuat oleh hasil wawancara yang dilakukan dengan guru kelas III, bahwa guru kelas tidak memberikan hadiah buku, tapi guru kelas memberikan hadiah seperti, pulpen dan buku gambar. Hasil wawancara menunjukkan bahwa 93\% peserta didik lebih tertarik membaca buku-buku cerita dibandingkan dengan buku pelajaran.

Hasil penelitian menunjukkan bahwa membeli buku yang menarik minat baca peserta didik rata-rata kelas III, membeli buku cerita untuk menarik di baca hal ini sesuai hasil obsevasi semua peserta didik kelas III membeli buku cerita bermacam-macam tapi salah satu buku tersebut ada satu buku yang disukainya.

\section{Berikan buku sebagai hadiah}

Berdasarkan hasil pengamatan, pada saat proses pembelajaran rata- rata peserta didik diberi hadiah oleh orang tua temen maupun saudaranya. Senada dengan hasil wawancara peserta didik didapatkan bahwa peserta didik kelas III, diberikan hadiah oleh orang tua maupun saudaranya berupa buku tulis, pulpen, dan baju batik. Hasil analisa data wawancara terkait memberikan buku sebagai hadiah menunjukkan $94 \%$ orang tua peserta didik maupun teman-temannya memberikan buku sebagai hadiah. Jenis buku yang diberikan sebagai hadiah adalah buku tulis, buku gambar, maupun buku mata pelajaran. Hasil penelitian menunjukkan 100\% peserta didik menyukai hadiah buku yang diberikan orangtua maupun teman-temannya.

Selanjutnya berdasar wawancara dapat disimpulkan, sebanyak $85 \%$ peserta didik tidak memberikan hadiah buku kepada teman-temannya. Pernyataan peserta didik tersebut diperkuat oleh hasil wawancara yang dilakukan dengan guru kelas III, bahwa peserta didik dapat hadiah dari orang tua, saudara maupun temannya, demikian juga dengan guru kelas memberikan hadiap berupa pujian, sesuatu benda, permen, dan buah yang dibawa dari rumah untuk hadiah.

Hasil penelitian dapat menyimpulkan bahwa Guru mengatakan peserta didik harus dipaksa membaca agar mereka mau dan dapat bercerita mengenai apa yang peserta didik baca. Guru juga memberikan tugas peserta didik ke perpustakaan, untuk membiasakan peserta didik membaca. Diamping itu hasil penelitian menunjukan bahwah memberi buku sebagai hadiah sudah diberikan baik orang tua peserta didik maupun sekolah hal ini sesuai dengan hasil observasi bahwa rata-rata peserta didik kelas III menyukai pemberian hadiah baik orang tua maupun pihak sekolah.

\section{Menyadiakan Waktu Membaca}

Hasil penelitian terkait penyediaan waktu membaca terhadap peserta didik kelas III pada umumnya peserta didik membaca buku dirumah setelah pulang sekolah, dan disekolah peserta didik dituntut untuk membaca buku sebelum jam pelajaran dimulai dalam waktu 15 menit. Dari hasil wawancara peserta didik yaitu didapatkan bahwa peserta didik kelas III, membaca buku di rumah jam 7 sampe jam 8 malam, kadang membaca buku komik dan buku pelajaran, hasil analisa data wawancara dapat disimpulkan sekitar $90 \%$ peserta didik membaca buku setelah pulang sekolah dan malam hari. Berdasarkan hasil penelitian dapat disimpulkan peserta didik diberikan waktu luang oleh guru di luar jam sekolah untuk membaca.

Setiap keluarga dianjurkan untuk memiliki perpustakaan keluarga, sehingga perpustakaan bisa dijadikan tempat yang menyenangkan ketika berkumpul bersama, sedangkan di tingkat sekolah rendahnya minat membaca peserta didik bisa diatasi dengan perbaikan perpustakaan sekolah, guru dan para pustakawan sekolah sebagai tenaga kependidikan, harus mengubah mekanisme proses pembelajaran menuju membaca sebagai suatu sistem pelajaran sepanjang hayat (Dalman, 2014). Dari berbagai pendapat yang telah dikemukakan diatas dapat disimpulkan bahwa minat baca seseorang tidaklah bisa tumbuh dengan sendirinya, tetapi membutuhkan peran orang lain untuk memotivasi atau upaya lain yang bisa menjadikan peserta didik termotivasi untuk membaca, dan hal penting lainnya adalah kuantitas dan kualitas bahan bacaannya.

\section{Pembahasan}

Upaya yang dapat dilalukan guru kelas untuk lebih meningkatkan minat baca pada peserta didik saat pembelajaran

Berdasarkan analisa data yang diperoleh, hasil penelitian menunjukkan bahwa upaya guru meningkatkan minat baca pada peserta didik kelas III SDN 202/IX Bukit Makmur telah dilaksanakan oleh pihak sekolah melalui penerapan program literasi. Program ini mewajibkan peserta didik untuk membaca 
buku selama 15 menit sebelum pelajaran di mulai. Program ini cukup baik dalam memotivasi peserta didik untuk membiasakan dan menumbuhkan minat membaca. Selain program literasi, pada saat proses pembelajaran guru memberikan motivasi kepada peserta didik untuk meningkatkan minat baca. Usaha guru untuk meningkatkan minat baca peserta didik dilakukan dengan cara meminta peserta didik pergi ke perpustakaan pada saat jam istirahat untuk meminjam buku yang peserta didik sukai.

Dalam penelitian ini untuk meningkatkan minat baca, peneliti mendalami beberapa upaya yang dapat dilaksanakan oleh guru kelas untuk meningkatkan minat baca peserta didik. Upaya yang dapat dilakukan adalah (1) Anjuran peserta didik bercerita tentang apa yang telah didengar atau dibacanya. Hasil penelitian menunjukkan bahwa upaya ini cukup baik dalam meningkatkan minat baca peserta didik. Hal ini dikarenakan guru kelas sangat berpartisipasi dalam memotivasi peserta didik untuk berani dan mau bercerita tentang hasil bacaannya di depan kelas. Kegiatan ini tidak saja mampu meningkatkan minat baca tetapi berdampak pada melatih kemampuan komunikasi dan keberanian peserta didik untuk bercerita di depan kelas.

Upaya berikutnya dalam peningkatan minat baca peserta didik adalah (2) Membeli buku yang menarik minat baca, upaya ini terbukti dapat meningkatkan minat baca. Meskipun kemampuan membeli buku akan berpengaruh pada kuantitas dan kualitas bahan bacaan peserta didik, tetapi paling tidak upaya ini dapat dilaksanakan oleh pihak orang tua, guru, pihak sekolah dan pihak lainnya dalam bentuk mendonasikan buku kepada perpustakaan sekolah.

Upaya selanjutnya (3) Bertukar buku dengan teman, upaya ini cukup efektif untk meningkatkan minat baca peserta didik. Hal ini dikarenakan dengan melakukan bertukar buku dengan teman, peserta didik dapat membaca buku yang lebih banyak dan beragam tema baik secara kuantitas dan kualitas. Upaya yang keempat (4) Memberikan buku sebagai hadiah, upaya ini juga terbukti dapat meningkatkan minat baca peserta didik. Faktor memberikan hadiah berupa buku, dapat memperkaya tema bacaan peserta didik dan juga dapat memberikan motivasi berbagai pihak baik peserta didik, orang tua, guru, sekolah dan pihak lainnya untuk memberikan hadiah berupa buku yang sangat berpengaruh positif bagi pertambahan dan perkembangan ilmu pengetahuan dan wawasan berpikir peserta didik. Upaya selanjutnya adalah (5) Menyediakan waktu membaca. Upaya ini terbukti cukup baik meningkatkan minat baca. Upaya ini lebih memberikan motivasi dan arahan kepada peserta didik untuk belajar mengatur dan memanfaatkan waktu untuk hal-hal yang bermanfaat.

Indikator untuk mengetahui minat membaca peserta didik kelas III ini diperoleh dari data kunjungan peserta didik ke perpustakaan untuk meminjam buku atau membaca buku pada saat jam istirahat. Adanya perkembangan minat peserta didik dalam membaca didukung oleh pendapat bahwa minat merupakan dorongan untuk memahami kata demi kata dan isi yang terkandung dalam teks bacaan tersebut, sehingga pembaca dapat memahami hal-hal yang dituangkan dalam bacaan itu. Hal ini sejalan dengan pendapat Tampubolon (1990) yang menjelaskan bahwa minat baca adalah kemauan atau keinginan seseorang untuk mengenali huruf untuk menangkap makna dari tulisan tersebut (Dalman, 2014).

Kegemaran membaca merupakan suatu tahapan menuju proses yang berkait erat dengan sebuah kerangka AIDA (attention, interest, desire, dan action)(Prasetyono, 2008). Keingin tahuan atau perhatian (attention) terhadap suatu objek dapat menimbulkan rasa ketertarikan atau menarik minat pada suatu (interest). Ketertarikan akan menimbulkan stimulus atau keinginan (desire) untuk melakukan sesuatu (membaca). Keinginan yang kuat dalam diri peserta didik akan menimbulkan semangat untuk terus membaca dalam memenuhi kebutuhan (action), sehingga peserta didik selalu berusaha untuk mendapatkan bacaan untuk memenuhi kebutuhannya. Keingin tahuan peserta didik sejalan dengan keingin tahuan guru dan perhatian (attention), rasa ketertarikan atau menarik minat pada sesuatu (interest). Ketertarikan akan menimbulkan rangsangan atau keinginan (desire) gairah untuk terus membaca untuk memenuhi kebutuhan (action).

Berdasarkan hasil penelitian dan konsep yang dikemukakan para ahli penulis mendukung pendapat tentang strategi menumbuhkan minat baca peserta didik dimulai sejak usia dini, kondisi ini akan berpengaruh kepada meningkatnya minat baca peserta didik. Minat baca peserta didik akan dapat ditingkatkan apabila sering dihadapkan dengan bacaan yang sesuai dengan kebutuhannya. Oleh karenanya, orang tua perlu memotivasi peserta didik dan sekaligus menerima kegiatan membaca untuk sebagai suatu kebutuhan. Apabila peserta didik sudah terbiasa melakukan kegiatan membaca, mereka akan gemar membaca dan bahkan pada tahap yang lebih lanjut akan menjadi wacana pemikiran bahwa membaca merupakan suatu kebutuhan hidupnya dan akhirnya akan tumbuh wawasan pemikiran tiada hari tanpa membaca.

\section{Upaya yang dapat dilalukan guru kelas untuk lebih meningkatkan minat baca pada peserta didik saat diluar jam pelajaran}

Hasil penelitian menunjukkan bahwa upaya guru meningkatkan minat baca pada peserta didik kelas III SDN 202/IX Bukit Makmur adalah dengan memberikan tugas dirumah untuk membaca. Hasil analisa data menunjukkan peserta didik kelas III rata-rata telah melaksanakan kegiatan membaca buku dirumah. Bahan 
bacaan yang dibaca peserta didik di rumah adalah buku mata pelajaran maupun buku cerita seperti buku cerita sikancil yang bijak, komik, majalah bobo, cerita robot, dan buku cerita princes.

Kegiatan membaca buku di rumah ini tentunya dipengaruhi faktar sarana prasarana pendukung agar kegiatan membaca dirumah dapat dilaksanakan dengan baik. Terkait hal ini sesuai dengan teori Hasyim (dalam Dalman, 2014) bahwa setiap keluarga memiliki perpustakaan keluarga, sehingga perpustakaan bisa dijadikan tempat yang menyenangkan ketika berkumpul bersama, sedangkan di tingkat sekolah, rendahnya minat membaca peserta didik-peserta didik dapat dioptimalkan melalui penyediaan fasilitas perpustakaan sesuai standar yang dipersyaratkan, peningkatan kompetensi dan pemahaman guru, maupun para pustakawan sekolah sebagai tenaga kependidikan, harus mengubah mekanisme proses pembelajaran menuju kegiatan membaca sebagai suatu sistem pelajaran sepanjang hayat.

Berdasarkan hasil analisa data, observasi peneliti dan pemaparan teori pendukung yang dikemukakan para ahli, peneliti dapat menyimpulkan bahwa minat baca seseorang tidaklah bisa tumbuh dengan sendirinya, tetapi membutuhkan peran orang lain untuk melakukan motivasi atau upaya lain yang bisa menjadikan peserta didik terangsang untuk membaca. Selain 5 (lima) upaya yang yang telah dipaparkan diatas faktor lain yang mempengaruhi minat baca adalah sarana prasarana perpustakaan yang baik dan juga faktor ketersediaan bahan bacaan yang yang optimal baik dari segi kuantitas dan kualitas.

\section{SIMPULAN}

Berdasarkan hasil penelitian dan pembahasan, dapat disimpulkan bahwa :

1. Dalam upaya guru meningkatkan minat baca pada peserta didik kelas III A SDN 202/IX BUKIT MAKMUR Pematang Pulai yaitu: (1) mendorong peserta didik bercerita tentang apa yang telah didengar atau dibacanya, (2) membeli buku yang menarik minat baca, (3) menukar buku dengan teman, (4) memberikan buku sebagai hadiah, dan (5) menyediakan waktu membaca.

2. Upaya guru kelas untuk lebih meningkatkan minat baca baca pada peserta didik saat luar jam pelajaran adalah memberikan tugas di rumah untuk membaca.

3. Peserta didik kelas III rata-rata membaca buku di rumah baik buku mata pelajaran maupun buku cerita seperti cerita sikancil yang bijak, komik, majalah bobo, cerita robot, dan buku cerita.

\section{DAFTAR PUSTAKA}

Bafadhal, Ibrahim. (2009). Peningkatan Profesionalisme Guru Sekolah Dasar Dalam Kerangka Manajemen Peningkatan Mutu Berbasis Sekolah.
Jakarta: Bumi Aksara.

Dalman. (2014). Keterampilan Membaca. Jakarta. Rajawali Pers.

Haryati, Mimin. (2008). Model dan Teknik Penilaian pada Tingkat Satuan Pendidikan. Jakarta: Gaung Persada Press.

Moleong, L. J. (2007). Metode Penelitian Kualitatif. Bandung: Remaja Rosdakarya.

Mulyasa, H.E. (2017). Menjadi Guru Profesional Menciptakan Pembelajaran Kreatif dan Menyenangkan. Jakarta: Rosda Karya.

Nuryanti, Lusi. (2008). Psikologi Peserta didik. Jakarta: Indeks.

Ormrod, J.E. (2008). Psikologi Pendidikan. Jakarta: Erlangga.

Prasetyono, Dwi Sunar (2008). Rahasia Mengajarkan Gemar Membaca Pada Peserta didik Sejak Dini. Yogyakarta: Think.

Prastowo, Andi. (2012). Metode Penelitian Kualitatif dalam Perspektif Rancangan Penelitiaan. Yogyakarta: Ar-Ruzz Media.

Rahim, Farida. (2008). Pengajaran Membaca Disekolah Dasar. Jakarta: Bumi Aksara.

Slameto. (2003) Belajar Dan Faktor-Faktor Yang Mempengaruhinya. Jakarta: Rineka Cipta.

Somadayo, Samsul.(2001). Strategi dan Teknik Pembelajaran Membaca. Yogyakarta: Graha Ilmu.

Sudarso. (2005). Speed Reading : Sistem Membaca Cepat dan Efektif. Jakarta: Gramedia Pustaka. 